\title{
Susceptibility loci for pancreatic cancer in the Brazilian population
}

\author{
Mateus Nóbrega Aoki ${ }^{1 *} \mathbb{D}$, Angelika Stein², Jaqueline Carvalho de Oliveira ${ }^{3}$, Roger Chammas ${ }^{4}$, Miyuki Uno ${ }^{4}$, \\ Francielle Boçon de Araújo Munhoz ${ }^{1}$, Anelis Maria Marin ${ }^{1}$ and Federico Canzian ${ }^{2}$
}

\begin{abstract}
Background: Pancreatic adenocarcinoma (PA) is a very aggressive cancer and has one of the poorest prognoses. Usually, the diagnosis is late and resistant to conventional treatment. Environmental and genetic factors contribute to the etiology, such as tobacco and alcohol consumption, chronic pancreatitis, diabetes and obesity. Somatic mutation in pancreatic cancer cells are known and SNP profile by GWAS could access novel genetic risk factors for this disease in different population context. Here we describe a SNP panel for Brazilian pancreatic cancer, together with clinical and epidemiological data.
\end{abstract}

Methods: 78 pancreatic adenocarcinoma and 256 non-pancreatic cancer subjects had 25 SNPs genotyped by realtime PCR. Unconditional logistic regression methods were used to assess the main effects on PA risk, using allelic, co-dominant and dominant inheritance models.

Results: 9 SNPs were nominally associated with pancreatic adenocarcinoma risk, with 5 of the minor alleles conferring protective effect while 4 related as risk factor. In epidemiological and clinical data, tobacco smoking, diabetes and pancreatitis history were significantly related to pancreatic adenocarcinoma risk. Polygenic risk scores computed using the SNPs in the study showed strong associations with PA risk.

Conclusion: We could assess for the first time some SNPs related with PA in Brazilian populations, a result that could be used for genetic screening in risk population such as familial pancreatic cancer, smokers, alcohol users and diabetes patients.

Keywords: Pancreatic cancer, SNP, Brazil, Association study, Genetic susceptibility

\section{Background}

Pancreatic adenocarcinoma (PA), although relative rare, is the seventh leading cause of cancer death worldwide [1] and is one of the cancers with the poorest prognosis, with a five year survival rate close to $10 \%$ [2]. A major cause for the poor prognosis is the late diagnosis and the resistance to conventional treatment [3] and, differently from other tumor types, mortality rates for PA are not improving $[4,5]$. In Brazil, PA was responsible for more

\footnotetext{
*Correspondence: mateus.aoki@fiocruz.br

${ }^{1}$ Laboratory for Applied Science and Technology in Health, Carlos Chagas Institute, Oswaldo Cruz Foundation (Fiocruz), Curitiba, PR, Brazil

Full list of author information is available at the end of the article
}

than 11,000 deaths in 2018, and PA incidence and lethality are increasing in the country $[6,7]$.

Environmental and genetic factors contribute to the etiology of PA, as the consumption of tobacco is an important risk factor $[8,9]$. Other risk factors include the excessive consumption of alcohol, chronic pancreatitis, diabetes, obesity and dietary-endocrine factors $[10,11]$.

Somatic mutation in pancreatic cells is an essential carcinogenesis event and strongly related with genes such as KRAS, CDKN2A, TP53, SMAD4. KRAS missense mutations include mainly three hot spots: glycine-12 (G12), glycine-12 (G13), or glutamine-61 (Q61), and occurs virtually in all PA cases [7-9]. Individuals with 
family history of pancreatic cancer have a higher risk of developing the disease and genetic susceptibility may be related to germinal mutations in known genes for hereditary cancer including CDKN2A, BRCA2, PALB2, STK11 and PRSS1 [6]. CDKN2A mutation are important in sporadic and familial events and it is estimated that this gene is altered in more than $90 \%$ of PA, with $0.6-3.3 \%$ of cases described to carry deleterious germline mutations in this gene $[12,13]$. BRCA2 also represents a hot-spot for rare variants/mutation for risk factor in PA[14, 15].

Also single nucleotide polymorphisms (SNPs) have been extensively studied for a possible association with the risk of PA, for example, polymorphisms in the cytochrome P450 enzyme (CYP2A6) have been linked to an increased risk of sporadic PA (independent of smoking) [16].

More recently, genome-wide association studies (GWAS) have identified common variants associated with risk of PA mainly in North American, European and Asian populations [17-20]. These studies highlight different loci but their frequency and PA risk association in the Brazilian population is unknown.

Based on this, the present study evaluated 25 SNPs, previously associated with PA risk in GWAS to investigate the influence of these loci in the Brazilian population, including 78 patients with pancreatic adenocarcinoma and 256 controls without cancer history. From the analyzed loci, 10 variants were associated with PA risk in some of the models analyzed, highlighting the importance of these regions.

\section{Methods}

\section{Study population}

In this prospective and consecutive study, we used 78 PA patients recruited from 2018 to 2019 with confirmation by histopathology and/or surgery provided from Academic Biobank of Research on Cancer from the University of São Paulo, located in Centro de Investigação Translacional em Oncologia, Instituto do Câncer do Estado de São Paulo (ICESP), São Paulo, Brazil. The Biobank protocol was approved by the Local Ethics Committee (CEP no. 031/12 and National Ethics Committee (CONEP no.023/2014). As control we used 256 subjects with non-pancreatic cancer, healthy blood donors or orthopedic patients provided from Hospital do Trabalhador, Curitiba PR, Brazil, with Local Ethics Committee (CEP CAAE no. 77979417.8.0000.5248 and 77979417.8.3001.5225) and National Ethics Committee (CONEP 77979417.8.0000.5248) approval. All approvals contemplated demographic and epidemiological data collection for both groups, while for PA cases clinical data were also collected. For all participants, the project was described and informed consent form was obtained in writing format. All the participants had $4 \mathrm{~mL}$ of peripheral blood collected and buffy-coat DNA was extracted with QIAmp DNA Blood Mini Kit (QIAGEN) as indicated. A quantification and purity of DNA were performed using NanoDrop One/OneC Microvolume UV Spectrophotometer ${ }^{\circledR}$ (Thermo Scientific).

\section{SNP selection}

For this study we initially selected 26 SNPs reported to be statistically associated with PA susceptibility or survival in previously GWAS studies $[18,21-26]$ to look for in the Brazilian population: rs11655237, rs2736098, rs351365, rs3790844, rs1486134, rs16986825, rs17688601, rs9581943, rs35226131, rs1561927, rs9854771, rs73328514, rs7310409, rs1517037, rs2853677, rs2941471, rs6971499, rs10991043, rs401681, rs13303010, rs9543325, rs4795218, rs7190458, rs10094872, rs684559 and rs353630. The last two SNPs were selected from a GWAS aimed at finding loci associated with survival of PA patients [26].

\section{Genotyping}

The SNP genotyping was conducted in the Genomic Epidemiology laboratory at the German Cancer Research Center (DKFZ), Heidelberg using TaqMan (ABI, Applied Biosystems, Foster City, CA) and KASP (KBioscence, Hoddesdon, UK) Technologies and TaqMan Genotyping Master Mix (Applied Bioscience) technology, according to the manufacturers' instructions. All samples were included in a 384-well plate. For quality control, duplicates of $5 \%$ of the samples were included. Polymerase chain reaction plates were read on a ViiA7 real time instrument (Applied Biosystems). The ViiA7 RUO Software, version 1.2.2 (Applied Biosystems), was used to determine genotypes. The genotyping concordance between duplicate samples exceeded 99\%, and samples with a call rate lower than $75 \%$ were discarded from the statistical analysis. rs35226131 was monomorphic in our population, therefore it was not included in further analyses.

\section{Statistical analysis}

Chi-square tests were used to compare sex, ethnicity, smoking and alcohol use, diabetes, pancreatitis between cases and controls, while for age we used t-student test, all conducted with Prism GraphPad. Hardy-Weinberg equilibrium was assessed in control subjects for each polymorphism. For each SNP, the more common allele in controls was assigned as the reference category. All analyses were adjusted for age and sex. Unconditional logistic regression methods were used to assess the main effects for the 25 selected genetic polymorphisms on PA risk, using allelic, co-dominant and dominant inheritance 
models. We used a $p<0.05$ threshold to assess statistically significant associations between SNPs and PA risk. Chisquare and Fisher's exact test was used to compare allele frequency between ethnic ancestry from PA patients, controls and reported in database, with statistically significant by $p<0.05$.

\section{Polygenic risk score}

We used the SNPs investigated in this study to assemble a polygenic risk score (PRS). We included all SNPs except rs684559 and rs353630, which were originally not reported to be associated with PA risk but rather with survival. For each SNP the number of alleles associated with higher PA risk were counted and added up for each study subject, resulting in an unweighted PRS. Additionally, we built a weighted PRS by using the ORs of the original GWASs. For each SNP in the weighted PRS a value of 0 was assigned if 0 risk alleles were present, $\ln (\mathrm{OR})$ was assigned if 1 risk allele was present, and $2 * \ln (\mathrm{OR})$ if 2 risk alleles were present. Then all the values were summed among them for each subject. Only a subset of the study subjects (67 cases and 228 controls) had a $100 \%$ SNP call rate. Therefore, in order to be able to compute comparable score values for all study subjects, we also considered "scaled" scores, in which the PRS values for each subject were multiplied by the ratio between the total number of SNPs and the number of effectively genotyped SNPs for the subject in question. For both PRSs (weighted and unweighted) we calculated quintiles based on the distribution of values in the controls.

The formulas for the unweighted and weighted scores are respectively $\sum_{1}^{m} a j$ and $\sum_{1}^{m} a X j$, where $a=$ number of risk alleles $(0,1,2), \mathrm{m}=$ total number of SNPs, $j=$ jth subject, $X=\ln (\mathrm{OR})$.

Additionally, we created also PRSs using only the 9 SNPs that show association with PA in this population. We analyzed the association between the quintiles of PRSs and PA risk by logistic regression, adjusting for age and sex.

\section{Results}

\section{Study population data}

Table 1 summarizes the epidemiological data for both groups. For the age, PA patients shows a mean age of 62.46 years old and the median age was 62 , while for the control group the ages were 56.62 and 57 , respectively. Age was not statistically different between cases and controls. The gender distribution was very similar with slightly more females among both cases and controls, which was also not statistically different. About ethnicity, collected as a self-reported variable, European ancestry people were more frequent in both groups $(66.7 \%$ in
Table 1 Epidemiological data for age, sex, ethnicity distribution, tobacco and alcohol use, diabetes, pancreatitis history and familial history of pancreatic cancer for both groups

\begin{tabular}{|c|c|c|c|}
\hline & PA cases & Controls & $p$ value \\
\hline Mean age (years) & 62.46 & 56.62 & 0.0842 \\
\hline Median Age (years) & 62 & 57 & - \\
\hline \multicolumn{4}{|l|}{ Sex } \\
\hline Male & $41 \%$ & $43 \%$ & \multirow[t]{2}{*}{0.9560} \\
\hline Female & $59 \%$ & $57 \%$ & \\
\hline \multicolumn{4}{|l|}{ Ethnicity } \\
\hline African ancestry & $32 \%$ & $17.5 \%$ & \multirow[t]{3}{*}{0.1303} \\
\hline European ancestry & $66.7 \%$ & $81.3 \%$ & \\
\hline Asian ancestry & $1.3 \%$ & $1.2 \%$ & \\
\hline \multicolumn{4}{|l|}{ Tobacco } \\
\hline Yes & 51.32 & 32.31 & \multirow[t]{2}{*}{0.0002} \\
\hline No & 48.68 & 67.69 & \\
\hline \multicolumn{4}{|l|}{ Alcohol } \\
\hline Yes & 31.58 & 32.31 & \multirow[t]{2}{*}{0.7774} \\
\hline No & 68.42 & 67.69 & \\
\hline \multicolumn{4}{|l|}{ Diabetes } \\
\hline Yes & 35.53 & 9.62 & \multirow[t]{2}{*}{$<0.0001$} \\
\hline No & 64.47 & 90.38 & \\
\hline \multicolumn{4}{|l|}{ Pancreatitis history } \\
\hline Yes & 10.53 & 0.77 & \multirow[t]{2}{*}{$<0.0001$} \\
\hline No & 89.47 & 99.23 & \\
\hline
\end{tabular}

PA and $81.3 \%$ in controls), while African ancestry people were more frequent in PA than controls $(32 \%$ and $17.5 \%$, respectively), again not statistically different. Other epidemiological data such as tobacco and alcohol usage, diabetes and personal pancreatitis history are also shown in Table 1. Statistical analysis showed a significant association between tobacco use $(p=0.002)$, diabetes $(p<0.0001)$ and pancreatitis history $(p<0.0001)$ and PA risk while alcohol use and familial PA history was not significant associated.

When we look for clinical data of the pancreatic cancer patients, almost $75 \%$ of then had the tumor located at pancreas head, while $8 \%$ was located in pancreatic body and $7 \%$ in tail and tail/body. For all 78 pancreatic cancer patients, 38 (49\%) were submitted to lymph node dissection, and 24 of then $(64 \%)$ present positivity with different ratio (Fig. 1). For treatment, $33 \%$ of the patients were treated with FOLFIRINOX, while $12 \%$ were submitted to surgery and $9 \%$ treated with gemcitabine.

For the genotyping analysis, all SNPs were in HWE in controls $(p>0.05)$. Results of association analysis between SNPs and PA risk are shown in Table 2. We found 8 SNPs that were nominally associated with pancreatic cancer risk $(p<0.05)$ with allelic model analysis and one more SNP with both codominant and dominant 


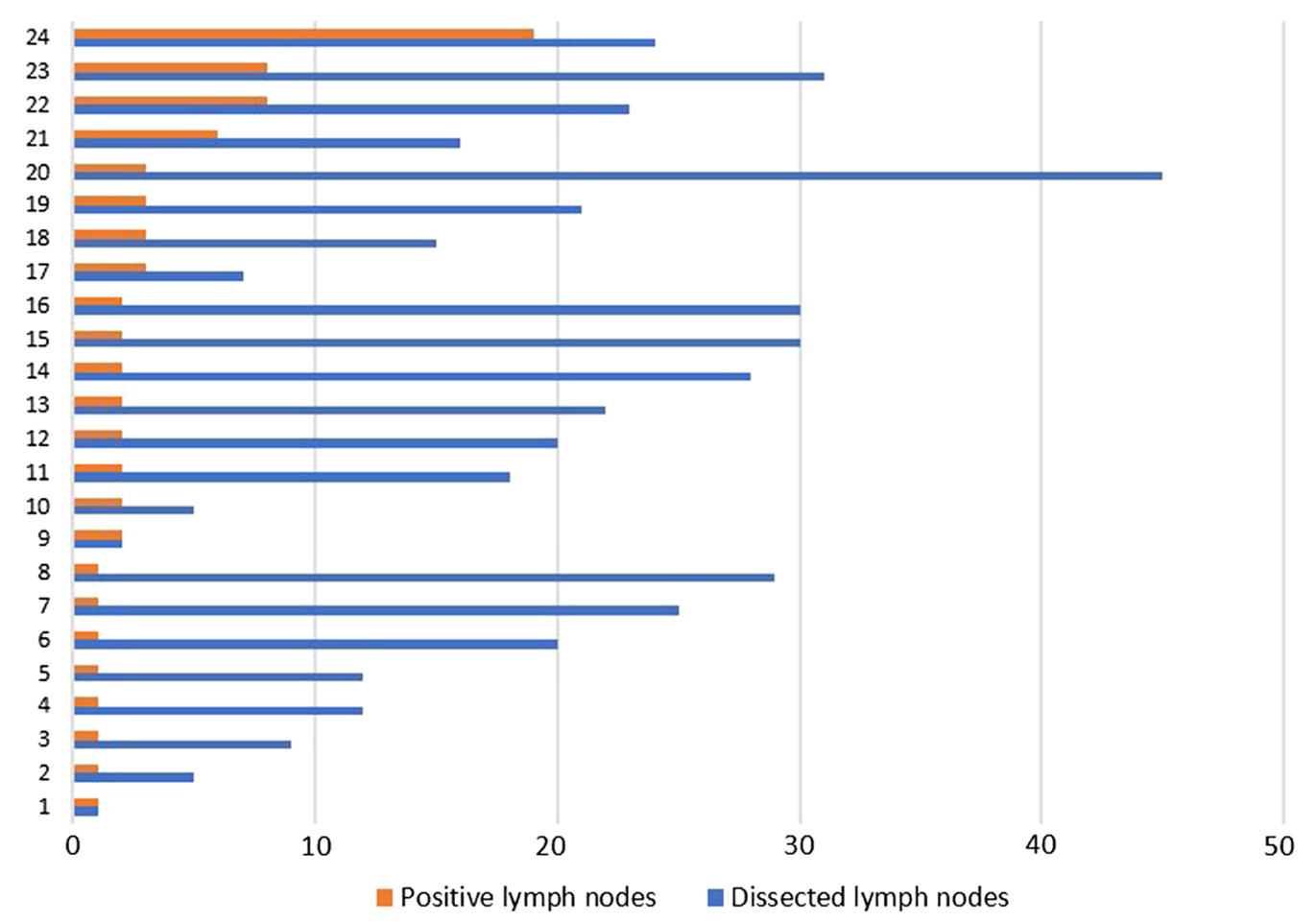

Fig. 1 Clinical data for lymph node dissection and positivity in PA patients

model analysis. Of these, the minor allele in 5 SNPs showed a protective effect for $\mathrm{PA}(\mathrm{OR}<1)$, while for 4 SNPs the minor allele was associated with increase in risk $(\mathrm{OR}>1)$. The most significant findings were related to SNPs rs3790844, rs9854771, rs2941471, rs401681, rs13303010 and rs9543325. For the first one the minor allele represents a protective effect in pancreatic cancer patients. In the same way, in the SNP rs9854771 the minor allele also represents a protective effect. The third SNP where the minor allele represents a protective effect is rs2941471. In a different way, at the SNP rs401681 the minor allele represents a risk factor for pancreatic cancer. At the SNP rs13303010 the minor allele also represents a risk factor for pancreatic cancer, again showed in SNP rs9543325. The complete results for analysis of the SNPs are shown in Table 2.

In Table 3 we demonstrate MAF for all nine statistically different SNPs obtained in dbSNP (https://www. ncbi.nlm.nih.gov/SNP/) database for African, European and Asian population. In the same table we demonstrate MAF for both PA patients and controls in the Brazilian population we studied, divided by ethnic ancestry.

All PRSs were associated with an increase in risk of PA, as expected. When we computed the association between the PRSs and PA risk considering only 67 cases and 228 controls with a call rate of $100 \%$, we observed an $\mathrm{OR}=6.83,95 \%$ CI $2.76-16.89, p=3.26 \times 10^{-5}$ for the highest vs. lowest quintile of the unweighted score and $\mathrm{OR}=16.77,95 \%$ CI $3.80-74.07, p=1.99 \times 10^{-4}$ for the highest vs. lowest quintile of the weighted score. Results were similar when we considered the whole dataset including 78 cases and 256 controls and "scaled" PRSs (Table 4), as well as when we assembled PRSs with only the 9 SNPs showing association with PA risk in this population (data not shown).

\section{Discussion}

The genetic PA risk factors in SNP context inherent to the Brazilian population have not been studied so far. Here we observed 9 SNPs associated with PA risk $(p<0.05)$ with the most significantly associated being rs3790844, rs9854771, rs2941471, rs401681, rs13303010 and rs9543325. A very important aspect in our results for these SNPs is that for all of them the OR is in the same direction of the original GWAS work.

The first SNP is located at the first intron of NR5A2, with MAF in global population of $25 \%$, and we observed a similar value of $27 \%$ in our control group, while in PA patients this value was $18 \%$, returning an OR that represents a protective effect of this allele for PA. In a meta-analysis by Chen et al., this SNP had a protective effect in Caucasians, although not in Asian populations [27]. However, another study with 360 pancreatic cancer patients and 400 controls suggested that this SNP is 


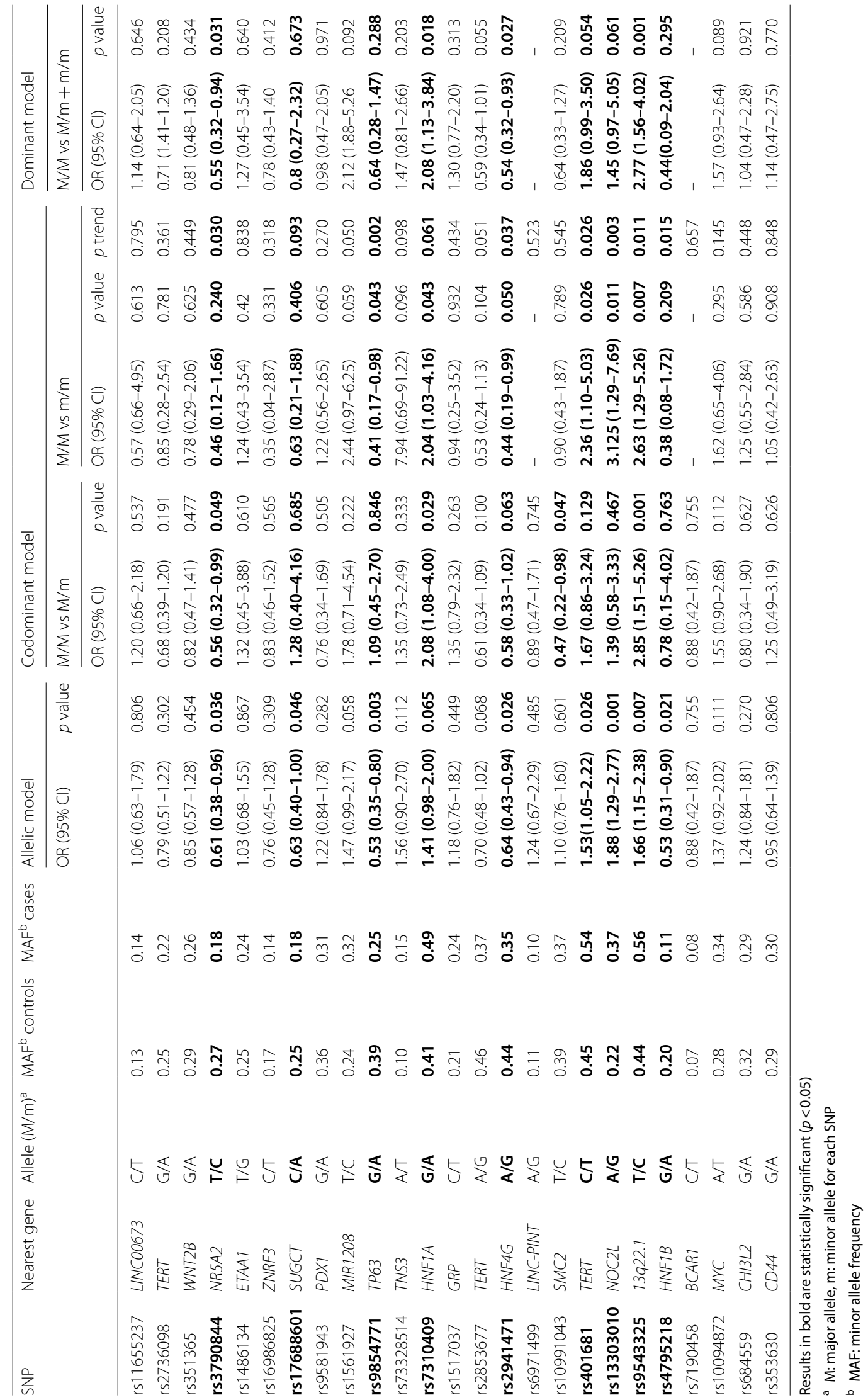


Table 3 MAF frequency for ethnic ancestry obtained in dbSNP database, PA patients and controls

\begin{tabular}{|c|c|c|c|c|c|c|c|c|c|}
\hline \multirow[b]{3}{*}{ SNP } & \multicolumn{9}{|c|}{ MAF frequency } \\
\hline & \multicolumn{3}{|c|}{ dbSNP database } & \multicolumn{3}{|l|}{ Brazilian PA } & \multicolumn{3}{|c|}{ Brazilian controls } \\
\hline & African & European & Asian & African (30) & European (62) & Asian (2) & African (45) & European (206) & Asian (4) \\
\hline rs3790844 & $0.13(6740)$ & $0.23(158,742)$ & $0.66(414)$ & 0.23 & 0.21 & 1.0 & $0.26^{* *}$ & 0.26 & 0.88 \\
\hline rs17688601 & 0.07 (2012) & $0.26(119,368)$ & $0.05(280)$ & 0.22 & 0.18 & 0.00 & $0.27^{* *}$ & 0.25 & 0.00 \\
\hline rs9854771 & $0.28(3086)$ & $0.36(93,526)$ & $0.14(238)$ & 0.23 & 0.27 & 0.00 & $0.47^{*} / * *$ & 0.38 & 0.00 \\
\hline rs7310409 & $0.32(6064)$ & $0.40(153,574)$ & $0.38(370)$ & 0.48 & 0.47 & 0.5 & 0.34 & 0.42 & 0.25 \\
\hline rs2941471 & $0.13(82)$ & $0.42(2072)$ & $0.50(4)$ & 0.65 & 0.67 & 0.5 & $0.41^{*} / * *$ & $0.44^{*}$ & 0.375 \\
\hline rs401681 & NA & NA & NA & 0.42 & 0.5 & 0.5 & 0.45 & 0.45 & 0.25 \\
\hline rs13303010 & $0.64(3306)$ & $0.10(117,068)$ & $0.27(186)$ & 0.35 & 0.33 & 0.25 & $0.35^{* *}$ & $0.19^{*}$ & 0.25 \\
\hline rs9543325 & $0.85(5580)$ & $0.37(153,016)$ & $0.46(370)$ & 0.45 & 0.49 & 0.25 & $0.61^{*} / * *$ & 0.40 & 0.5 \\
\hline rs4795218 & $0.06(82)$ & $0.21(2072)$ & $0.5(4)$ & 0.13 & 0.15 & 0.00 & 0.14 & 0.22 & 0.2 \\
\hline
\end{tabular}

For dbSNP Database values indicated are MAF followed by sample number. For Brazilian PA and controls, MAF are represented according to self-reported ethnic ancestry followed by sample number

* Statistical difference $(p<0.05)$ between allele frequency in Brazilian PA patients and controls related to the same ancestry

** Statistical difference $(p<0.05)$ between allele frequency in Brazilian controls and dbSNP Database related to the same ancestry

Table 4 Associations between PRSs and PA risk

\begin{tabular}{|c|c|c|c|c|}
\hline Type of score & Quintiles & $O R^{a}$ & $95 \% \mathrm{Cl}^{\mathrm{a}}$ & $p_{\text {value }}$ \\
\hline \multirow[t]{6}{*}{ Unweighted, subjects with $100 \%$ call rate } & 1 & 1.00 & - & Ref \\
\hline & 2 & 0.44 & $0.09-2.25$ & 0.327 \\
\hline & 3 & 2.61 & $0.97-7.01$ & 0.057 \\
\hline & 4 & 3.29 & $1.15-9.37$ & 0.026 \\
\hline & 5 & 6.83 & $2.76-16.89$ & $3.26 \times 10^{-5}$ \\
\hline & Continuous $^{b}$ & 1.73 & $1.40-2.15$ & $4.30 \times 10^{-7}$ \\
\hline \multirow[t]{6}{*}{ Unweighted scaled, all subjects } & 1 & 1.00 & - & Ref \\
\hline & 2 & 0.65 & $0.16-2.60$ & 0.539 \\
\hline & 3 & 2.22 & $0.86-5.73$ & 0.097 \\
\hline & 4 & 4.03 & $1.57-10.37$ & 0.004 \\
\hline & 5 & 6.70 & $2.86-15.69$ & $1.21 \times 10^{-5}$ \\
\hline & Continuous $^{\mathrm{b}}$ & 1.72 & $1.41-2.10$ & $1.02 \times 10^{-7}$ \\
\hline \multirow[t]{6}{*}{ Weighted, subjects with $100 \%$ call rate } & 1 & 1.00 & - & Ref \\
\hline & 2 & 2.15 & $0.39-11.75$ & 0.376 \\
\hline & 3 & 3.51 & $0.71-17.29$ & 0.122 \\
\hline & 4 & 4.90 & $1.02-23.56$ & 0.047 \\
\hline & 5 & 16.77 & $3.80-74.07$ & $1.99 \times 10^{-4}$ \\
\hline & Continuous $^{\mathrm{b}}$ & 2.05 & $1.58-2.65$ & $4.98 \times 10^{-8}$ \\
\hline \multirow[t]{6}{*}{ Weighted scaled, all subjects } & 1 & 1.00 & - & Ref \\
\hline & 2 & 1.37 & $0.41-4.62$ & 0.613 \\
\hline & 3 & 2.07 & $0.67-6.44$ & 0.209 \\
\hline & 4 & 3.22 & $1.08-9.60$ & 0.036 \\
\hline & 5 & 8.13 & $2.95-22.43$ & $5.12 \times 10^{-5}$ \\
\hline & Continuous ${ }^{b}$ & 1.76 & $1.42-2.17$ & $2.28 \times 10^{-7}$ \\
\hline
\end{tabular}

$\mathrm{M}$, major allele; $\mathrm{m}$, minor allele for each SNP; MAF, minor allele frequency

a OR: odds ratio; $\mathrm{Cl}$ : confidence interval; all analyses were adjusted for age and sex

b The unit for the analysis with the continuous variable was the increment of one quintile 
related with pancreatic cancer risk in Japanese subjects [27]. A large study using 3851 pancreatic cancer cases and 3934 controls participants from the previously conducted GWAS in the Pancreatic Cancer Cohort Consortium and the Pancreatic Cancer Case Control Consortium (PanC4) $[17,28]$ showed this SNP as the most significant risk factor for pancreatic cancer, with an OR of 0.77, again representing a protective effect of minor allele [29].

The SNP rs9854771 has a MAF in global population of $37 \%$. In our control group we observed a similar MAF of $39 \%$, while in PA cases it was $25 \%$. This SNP is located near TP63 gene, that is a p53 homologue and implicated in tumorigenesis and metastasis [30], and previous GWAS studies have demonstrated significant evidence of association for SNPs in TP63 in lung cancer and bladder cancer [31-35]. The first description of its role in pancreatic cancer was revealed by Childs[25] with an OR of 0.89 and a subsequent study [36] returned a similar result with an OR 0.76 .

A third SNP where the minor allele is associated with a reduction in PA risk is rs2941471 and its MAF in global population is $41 \%$. Here, the control group show a MAF of $44 \%$, while in the PA cases it is $35 \%$. This SNP is located is an intronic region of $H N F 4 G$ gene, at chromosome 8q21.11, which encodes hepatocyte nuclear factor 4 gamma, a transcription factor of the nuclear receptor superfamily whose expression level was increased in five of six clinical human hepatocellular carcinoma samples[37]. When related with pancreas, mice lacking HNF4G have higher numbers of pancreatic $\beta$-cells, increased glucose-induced insulin secretion and improved glucose tolerance [38]. A research showing GWAS pathways associated with pancreatic cancer susceptibility factors proposed a link between HNF4G inherited variation for pancreatic development [29]. A very consistent research with 2737 pancreatic cancer patients and 4752 controls also yielded this SNP as a genome-wide significant locus ( $\mathrm{OR}=0.87)$ [21].

For SNP rs9543325, the global MAF is $38 \%$, similar the frequency of $44 \%$ found in our control Brazilian population. In PA, this value increased to $56 \%$ and was associated with increased risk for pancreatic cancer in all models analyzed. This association was previously showed in Europeans [28, 39], including Jewish and non-Jewish [40], and in the Taiwanese population [41]. This intergenic SNP maps at 13q22.1 locus, and has been showed to be strongly associated with pancreatic cancer $[1,3$, 36, 40-42]. The locus 13q22.1 has other SNPs associated previously with PA, mainly in European and Chinese populations, some studies suggest a potential long-range enhancer activity but mechanisms are still unknown [43].

The SNP rs13303010 has a global population MAF of $12 \%$. In our control group this value was increased to
$22 \%$ and, among PA patients this frequency increased to $37 \%$ and was associated with high cancer risk. The minor allele was also associated with increased PA risk in European [21] and Japanese populations [44]. In European populations, it was highlighted in PA susceptibility only in the largest pancreatic cancer GWAS to date, including 11,537 patients and 17,107 controls from the Pancreatic Cancer Cohort Consortium (PanScan I+ II, III), Pancreatic Cancer Case-Control Consortium (PanC4) and PANcreatic Disease ReseArch (PANDoRA) consortium [21]. In the Japanese population, 664 pancreatic cancer cases and 664 controls were analyzed and this SNP was highlighted as PA risk factor [44]. This SNP is mapped at $1 \mathrm{p} 36.33$, in the first intron of the NOC2L gene and probably influences the host expression. The presence of the risk-increasing allele was associated with higher NOC2L expression [21] and this gene encodes the NOC2 like nucleolar associated transcriptional repressor, a protein that represents a novel histone deacetylases-independent inhibitor of histone acetyltransferase [45]. NOC2-like protein has also been associated with the inhibition of p53 and p63 tumor suppressor $[46,47]$, notably associated with cancer.

The rs401681 is a SNP located in the intron of CLPTM $1 L$ and $27 \mathrm{~kb}$ from the TERT gene, being associated with many tumor types $[48,49]$. The global population MAF is $43 \%$ and, in the Brazilian population, we found a similar frequency of $45 \%$ in the control group. In the present study, the presence of the minor allele represents a risk factor for pancreatic cancer. This high risk for PA was also shown in European [17, 39, 50] and Asian populations [51, 52]. It is suggested that rs 401681 confers cancer susceptibility by regulating CLPTM1L and TERT expression [53], both genes implicated in carcinogenesis. CLPTM1L gene may be associated in apoptosis processes and high expressed in cisplatin-resistant cell lines [54], TERT gene produce catalytic subunit of telomerase, associated with telomere maintaining and usually active in cancer cells [55]. An interesting aspect in rs401681 is that the minor allele is usually associated with increased risk in pancreatic cancer and in melanoma [56] whereas the $\mathrm{C}$ allele was associated with increased risk of other tumor types, such as lung, prostate and bladder [48].

Some other SNPs showed statistically significant associations with PA risk in this work. The minor allele of rs17688601, in SUGCT gene, and rs4795218, in HNF1B gene, were associated with reduced risk in the European population [21, 25]. In the Brazilian population we found them also associated with protection, but only in allelic model. On the other hand, another SNP previously associated SNP in Europeans, the rs7310409 in HNF1A, was associated with risk in dominant and co-dominant models, but not in allelic analysis $(p=0.065)$. The other SNPs 
analyzed were not associated with PA in the Brazilian population in the present study.

Ethnic differences in pancreatic cancer incidence have been reported, especially regarding higher incidence in African in relation with European ancestries [57-59]. Some studies suggested that this higher pancreatic cancer incidence in African ancestry may be partially explained by the greater prevalence of smoking, diabetes, and obesity among these group with no genetic investigation [58, 60]. A recent report demonstrated that family history of pancreatic cancer, diabetes, body mass index $\geq 30 \mathrm{~kg} / \mathrm{m}^{2}$, current smoking, and red meat intake were associated with pancreatic cancer. More than that, after adjustment for these risk factors, Native Hawaiians, Japanese Americans, and African Americans but not Latino Americans had a higher risk of pancreatic cancer compared to European Americans, showing the genetic influence in pancreatic cancer incidence [61]. Regarding ethnic ancestry on this report, Brazil represents a heterogeneous country with European, African and Asian descendants. Interestingly, statistically significant difference between MAF in PA patients and controls in Brazilian population was observed just in 3 SNPs in African and 2 in European ancestry. In this context, SNPs rs 9854771 and rs 9543325 were observed as a higher MAF in African ancestry Brazilian controls than PA African Brazilian patients. On the other hand, SNP rs2941471 represent a lower MAF in Brazilian controls than PA patients for both African and European ancestry, the same trend observed for SNP rs13303010 in European ancestry. But when MAF frequency was compared between Brazilian controls and dbSNP data, six SNPs were statistically significantly different, but all in African ancestry. These data demonstrate that self-reported African ancestry from Brazilian controls presents a different genetic SNP profile when compared to African population, probably due to ethnic miscegenation.

PRSs computed with the SNPs we included in the study show a strong association with PA risk when comparing the $20 \%$ of the population with highest and lowest PRS values. The small sample size results in very wide confidence intervals of our risk estimates, but the results are in line with a those of a recent study in a much larger population of European origin [62]. It is expected that smaller groups at the extremes of the PRS distribution (e.g. the $5 \%$ or $1 \%$ with highest/lowest PRS values) will show even more marked differences in risk.

\section{Conclusion}

The main limitation of this study is small sample size. However, as our target SNPs were previously reported as susceptibility loci for PA in large GWAS studies, mainly conducted with European population, this small sample size could establish for the first time SNPs as genetic risk factor for PA in Brazil. Despite a considerable percentage of Amerindian, African and Asian descent in the Brazilian population, the largest ethnic component is European ancestry, showing that genetic risk factors related to Europeans are at least partially reflected in the Brazilian population. This was partially demonstrated by MAF frequency from European ancestry in Brazilian controls and dbSNP database, where no difference was observed. In contrary, Brazilian controls from African ancestry showed MAF statistically significantly different in six out of nine SNPs. Associations of several SNPs reported to affect PA risk in populations of European descent were successfully replicated in our study. Given the limitation of sample size it is not possible to assess whether the SNPs that did not replicate in this work are relevant or not in the Brazilian population. However, it is worth nothing that even for the SNPs that do not reach $p<0.05$, the direction of the associations (i.e. whether the minor allele is associated with increase or decrease in risk) was consistent with the GWAS data. Our group is recruiting more PA patients and with this data we will have more power in future analyses.

These data can be used for stratification of PA risk, especially in groups that are already known to be at increased risk, such as people with positive family history of pancreatic cancer, and in subjects with high tobacco and alcohol use. PRS can be particularly useful in this context, as shown by our results. More important, this is the first genetic susceptibility study for pancreatic adenocarcinoma in Brazilian population.

\section{Abbreviations}

PA: Pancreatic adenocarcinoma; SNP: Single nucleotide polymorphism; GWAS: Genome-wide association studies; PRS: Polygenic Risk Score; OR: Odds ratio; HWE: Hardy-Weinberg equilibrium; MAF: Minor allele frequency.

\section{Acknowledgements \\ We would like to thank Diogo Araújo and Maria José Ferreira Alves for PA samples processing.}

\section{Authors' contributions}

MNA and FC conceived and designed the study. MNA and AS performed the experiments and data analysis. RC and MU organized and conducted the PA sample collection, as participated in data interpretation and analysis. MNA and JCO conducted controls sample collection, together with data interpretation and analysis. FBAM and AMM made manuscript corrections and substantively revised it. MNA, FC drafted the paper. All authors had substantively intellectual contributions, read and approved the manuscript, and agreed to be personally accountable for the author's own contributions. All authors read and approved the final manuscript.

Funding

This work was supported by Fiocruz and Carlos Chagas Institute, especially grant "Geração de conhecimento - Novos Talentos", and intramural funding of DKFZ, providing financial support for samples collection and processing besides data generation and analysis. Open access was enabled through BMC Medical Genomics waiver. 


\section{Availability of data and material}

Owing to ethical and legal reasons, providing participants individual raw data of this study are not publicly deposited, and will be made available to researchers who submit a reasonable request to the corresponding author (mateus.aoki@fiocruz.br),conditional to approval by competent IRBs. Data will be stripped from all information allowing identification of study participants. Furthermore, additional work and data analyze is being carried out for further studies.

\section{Declarations}

\section{Ethics approval and consent to participate}

The Project was conducted after Local Ethics Committee approval for pancreatic cancer (process 031/12 from Instituto do Câncer do Estado de São Paulo and process no.023/2014 from National Ethics Committee from Conselho Nacional de Ética em Pesquisa) and controls (process CAAE no. 77979417.8.0000.5248 and 77979417.8.3001.5225 from Fundação Oswaldo Cruz and Hospital do Trabalhador) and National Ethics Committee (process 77979417.8.0000.5248 from Conselho Nacional de Ética em Pesquisa). All approvals also contemplated clinical and personal data collections. For all participants, the project was described and informed consent form was obtained in writing format, with one copy remaining in the participant's possession.

\section{Consent for publication}

Not applicable.

\section{Competing interests}

The authors declare no conflict of interest.

\section{Author details}

${ }^{1}$ Laboratory for Applied Science and Technology in Health, Carlos Chagas Institute, Oswaldo Cruz Foundation (Fiocruz), Curitiba, PR, Brazil. ${ }^{2}$ Genomic Epidemiology Group, German Cancer Research Center (DKFZ), Heidelberg, Germany. ${ }^{3}$ Department of Genetics, Federal University of Parana, Curitiba, Brazil. ${ }^{4}$ Departamento de Radiologia E Oncologia, Centro de Investigação Translacional Em Oncologia, Instituto Do Câncer Do Estado de São Paulo (ICESP), Faculdade de Medicina da Universidade de São Paulo (FMUSP), São Paulo, Brasil.

Received: 29 July 2020 Accepted: 8 April 2021

Published online: 20 April 2021

\section{References}

1. Bray F, Ferlay J, Soerjomataram I, Siegel RL, Torre LA, Jemal A, Global cancer statistics. GLOBOCAN estimates of incidence and mortality worldwide for 36 cancers in 185 countries. CA Cancer J Clin. 2018;68(2018):394-424.

2. Siegel RL, Miller KD, Jemal A. Cancer statistics, 2020. CA Cancer J Clin. 2020;70:7-30

3. Chand S, O'Hayer K, Blanco FF, Winter JM, Brody JR. The landscape of pancreatic cancer therapeutic resistance mechanisms. Int J Biol Sci. 2016;12:273-82.

4. Klein AP. Pancreatic cancer: a growing burden. Lancet Gastroenterol Hepatol. 2019:4:895-6.

5. Rahib L, Smith BD, Aizenberg R, Rosenzweig AB, Fleshman JM, Matrisian LM. Projecting cancer incidence and deaths to 2030: the unexpected burden of thyroid Liver, and Pancreas Cancers in the United States. Cancer Res. 2014;74:2913-21.

6. Perrotta de Souza LM, Moreira JPL, Fogaça HS, Luiz RR, de Souza HS. Pancreatic cancer incidence and lethality rates in Brazil. Pancreas. 2017:46:699-706.

7. Bigoni A, FerreiraAntunes JL, Weiderpass E, Kjærheim K. Describing mortality trends for major cancer sites in 133 intermediate regions of Brazil and an ecological study of its causes. BMC Cancer. 2019;19:940.

8. Rawla P, Sunkara T, Gaduputi V. Epidemiology of Pancreatic Cancer: Global Trends, Etiology and Risk Factors. World J Oncol. 2019;10:10-27.

9. Mizrahi JD, Surana R, Valle JW, Shroff RT. Pancreatic cancer. Lancet. 2020;395:2008-20.
10. Er K-C, Hsu C-Y, Lee Y-K, Huang M-Y, Su Y-C. Effect of glycemic control on the risk of pancreatic cancer. Medicine (Baltimore). 2016;95:e3921.

11. Li D, Abbruzzese JL. New strategies in pancreatic cancer: emerging epidemiologic and therapeutic concepts. Clin Cancer Res. 2010;16:4313-8.

12. Amundadottir LT. Pancreatic cancer genetics. Int J Biol Sci. 2016;12:314-25.

13. McWilliams RR, Wieben ED, Rabe KG, Pedersen KS, Wu Y, Sicotte $H$, Petersen GM. Prevalence of CDKN2A mutations in pancreatic cancer patients: implications for genetic counseling. Eur J Hum Genet. 2011;19:472-8.

14. Hu C, LaDuca H, Shimelis H, Polley EC, Lilyquist J, Hart SN, Na J, Thomas A, Lee KY, Davis BT, Black MH, Pesaran T, Goldgar DE, Dolinsky JS, Couch FJ. Multigene hereditary cancer panels reveal high-risk pancreatic cancer susceptibility genes. JCO Precis Oncol. 2018;2018:1-28.

15. Hu C, Hart SN, Polley EC, Gnanaolivu R, Shimelis H, Lee KY, Lilyquist J, Na J, Moore R, Antwi SO, Bamlet WR, Chaffee KG, DiCarlo J, Wu Z, Samara R, Kasi PM, McWilliams RR, Petersen GM, Couch FJ. Association between inherited germline mutations in cancer predisposition genes and risk of pancreatic cancer. JAMA. 2018;319:2401.

16. Kadlubar S, Anderson JP, Sweeney C, Gross MD, Lang NP, Kadlubar FF, Anderson KE. Phenotypic CYP2A6 variation and the risk of pancreatic cancer. JOP. 2009;10:263-70.

17. Amundadottir L, Kraft P, Stolzenberg-Solomon RZ, Fuchs CS, Petersen GM, Arslan AA, Bueno-de-Mesquita HB, Gross M, Helzlsouer K, Jacobs EJ, LaCroix A, Zheng W, Albanes D, Bamlet W, Berg CD, Berrino F, Bingham S, Buring JE, Bracci PM, Canzian F, Clavel-Chapelon F, Clipp S, Cotterchio M, de Andrade M, Duell EJ, Fox JW Jr, Gallinger S, Gaziano JM, Giovannucci EL, Goggins M, González CA, Hallmans G, Hankinson SE, Hassan M, Holly EA, Hunter DJ, Hutchinson A, Jackson R, Jacobs KB, Jenab M, Kaaks R, Klein AP, Kooperberg C, Kurtz RC, Li D, Lynch SM, Mandelson M, McWilliams RR, Mendelsohn JB, Michaud DS, Olson SH, Overvad K, Patel AV, Peeters PHM, Rajkovic A, Riboli E, Risch HA, Shu X-O, Thomas G, Tobias GS, Trichopoulos D, Van Den Eeden SK, Virtamo J, Wactawski-Wende J, Wolpin BM, Yu H, Yu K, Zeleniuch-Jacquotte A, Chanock SJ, Hartge P, Hoover RN. Genomewide association study identifies variants in the $A B O$ locus associated with susceptibility to pancreatic cancer. Nat Genet. 2009;41:986-90.

18. Ueno M, Ohkawa S, Morimoto M, Ishii H, Matsuyama M, Kuruma S, Egawa N, Nakao H, Mori M, Matsuo K, Hosono S, Nojima M, Wakai K, Nakamura K, Tamakoshi A, Takahashi M, Shimada K, Nishiyama T, Kikuchi S, Lin Y. Genome-wide association study-identified SNPs (rs3790844, rs3790843) in the NR5A2 gene and risk of pancreatic cancer in Japanese. Sci Rep. 2015;5:17018.

19. Witkiewicz AK, McMillan EA, Balaji U, Baek G, Lin W-C, Mansour J, Mollaee M, Wagner K-U, Koduru P, Yopp A, Choti MA, Yeo CJ, McCue P, White MA Knudsen ES. Whole-exome sequencing of pancreatic cancer defines genetic diversity and therapeutic targets. Nat Commun. 2015;6:6744.

20. Waddell N, Pajic M, Patch A-M, Chang DK, Kassahn KS, Bailey P, Johns AL, Miller D, Nones K, Quek K, Quinn MCJ, Robertson AJ, Fadlullah MZH, Bruxner TJC, Christ AN, Harliwong I, Idrisoglu S, Manning S, Nourse C, Nourbakhsh E, Wani S, Wilson PJ, Markham E, Cloonan N, Anderson MJ, Fink JL, Holmes O, Kazakoff SH, Leonard C, Newell F, Poudel B, Song S, Taylor D, Waddell N, Wood S, Xu Q, Wu J, Pinese M, Cowley MJ, Lee HC, Jones MD, Nagrial AM, Humphris J, Chantrill LA, Chin V, Steinmann AM, Mawson A, Humphrey ES, Colvin EK, Chou A, Scarlett CJ, Pinho AV, GiryLaterriere M, Rooman I, Samra JS, Kench JG, Pettitt JA, Merrett ND, Toon C, Epari K, Nguyen NQ, Barbour A, Zeps N, Jamieson NB, Graham JS, Niclou SP, Bjerkvig R, Grützmann R, Aust D, Hruban RH, Maitra A, lacobuzioDonahue CA, Wolfgang CL, Morgan RA, Lawlor RT, Corbo V, Bassi C, Falconi M, Zamboni G, Tortora G, Tempero MA, Gill AJ, Eshleman JR, Pilarsky C, Scarpa A, Musgrove EA, Pearson JV, Biankin AV, Grimmond SM. Whole genomes redefine the mutational landscape of pancreatic cancer. Nature. 2015;518:495-501.

21. Klein AP, Wolpin BM, Risch HA, Stolzenberg-Solomon RZ, Mocci E, Zhang M, Canzian F, Childs EJ, Hoskins JW, Jermusyk A, Zhong J, Chen F, Albanes D, Andreotti G, Arslan AA, Babic A, Bamlet WR, Beane-Freeman L, Berndt SI, Blackford A, Borges M, Borgida A, Bracci PM, Brais L, Brennan P, Brenner H, Bueno-De-Mesquita B, Buring J, Campa D, Capurso G, Cavestro GM, Chaffee KG, Chung CC, Cleary S, Cotterchio M, Dijk F, Duell EJ, Foretova L, Fuchs C, Funel N, Gallinger S, Gaziano JMM, Gazouli M, Giles GG, Giovannucci E, Goggins M, Goodman GE, Goodman PJ, Hackert T, Haiman C, Hartge P, Hasan M, Hegyi P, Helzlsouer KJ, Herman J, Holcatova I, Holly 
EA, Hoover R, Hung RJ, Jacobs EJ, Jamroziak K, Janout V, Kaaks R, Khaw KT, Klein EA, Kogevinas M, Kooperberg C, Kulke MH, Kupcinskas J, Kurtz RJ, Laheru D, Landi S, Lawlor RT, Lee IM, Lemarchand L, Lu L, Malats N, Mambrini A, Mannisto S, Milne RL, Mohelníková-Duchoňová B, Neale RE, Neoptolemos JP, Oberg AL, Olson SH, Orlow I, Pasquali C, Patel AV, Peters U, Pezzilli R, Porta M, Real FX, Rothman N, Scelo G, Sesso HD, Severi G, Shu XO, Silverman D, Smith JP, Soucek P, Sund M, Talar-Wojnarowska R, Tavano F, Thornquist MD, Tobias GS, Van Den Eeden SK, Vashist Y, Visvanathan K, Vodicka P, Wactawski-Wende J, Wang Z, Wentzensen N, White E, Yu H, Yu K, Zeleniuch-Jacquotte A, Zheng W, Kraft P, Li D, Chanock S, Obazee O, Petersen GM, Amundadottir LT. Genome-wide meta-analysis identifies five new susceptibility loci for pancreatic cancer. Nat Commun. 2018;9:1-11.

22. Petersen GM, Amundadottir L, Fuchs CS, Kraft P, Stolzenberg-Solomon RZ, Jacobs KB, Arslan AA, Bueno-De-Mesquita HB, Gallinger S, Gross M, Helzlsouer K, Holly EA, Jacobs EJ, Klein AP, Lacroix A, Li D, Mandelson MT, Olson $\mathrm{SH}$, Risch HA, Zheng W, Albanes D, Bamlet WR, Berg CD, Boutron-Ruault MC, Buring JE, Bracci PM, Canzian F, Clipp S, Cotterchio M, De Andrade M, Duell EJ, Gaziano JM, Giovannucci EL, Goggins M, Hallmans G, Hankinson SE, Hassan M, Howard B, Hunter DJ, Hutchinson A, Jenab M, Kaaks R, Kooperberg C, Krogh V, Kurtz RC, Lynch SM, McWilliams RR, Mendelsohn JB, Michaud DS, Parikh H, Patel AV, Peeters PHM, Rajkovic A, Riboli E, Rodriguez L, Seminara D, Shu XO, Thomas G, Tjønneland A, Tobias GS, Trichopoulos D, Van Den Eeden SK, Virtamo J, Wactawski-Wende J, Wang Z, Wolpin BM, Yu H, Yu K, Zeleniuch-Jacquotte A, Fraumeni JF, Hoover RN, Hartge P, Chanock SJ. A genome-wide association study identifies pancreatic cancer susceptibility loci on chromosomes 13q22.1, 1q32.1 and 5p15.33. Nat Genet. 2010;42:224-8.

23. Zhang M, Wang Z, Obazee O, Jia J, Childs EJ, Hoskins J, Figlioli G, Mocci E, Collins I, Chung CC, Hautman C, Arslan AA, Beane-Freeman L, Bracci PM, Buring J, Duell EJ, Gallinger S, Giles GG, Goodman GE, Goodman PJ, Kamineni A, Kolonel LN, Kulke MH, Malats N, Olson SH, Sesso HD, Visvanathan K, White E, Zheng W, Abnet CC, Albanes D, Andreotti G, Brais L, Bueno HB, Krogh V, Kupcinskas J, Kurtz RC, Landi MT, Landi S, Le Marchand L, Mambrini A, Mannisto S, Milne RL, Neale RE, Oberg AL, Panico S, Patel AV, Peeters PHM, Peters U, Pezzilli R, Porta M, Purdue M, Quiros JR, Riboli E, Rothman N, Scarpa N, Scelo G, Shu XO, Silverman DT, Soucek P, Strobel O, Sund M, Małecka-Panas E, Taylor PR, Tavano F, Travis RC, Thornquist M, Tjønneland A, Tobias GS, Trichopoulos D, Vashist Y, Vodicka P, Wactawski-Wende J, Wentzensen N, Yu H, Yu K, Zeleniuch-Jacquotte A, Kooperberg C, Risch HA, Jacobs EJ, Li D, Fuchs C, Hoover R, Hartge P, Chanock SJ, Petersen GM, Stolzenberg-Solomon RS, Wolpin BM, Kraft P, Klein AP, Canzian F. Amundadottir, Laurie Burdette 2,3 , Daniele Campa 40 , Neil E. Caporaso 2, Gabriele Capurso 41 , Giulia Martina Cavestro 42 , Michelle Cotterchio 43, Elzbieta Iskierka-Jazdzewska. 2021;7, 35.

24. Wolpin BM, Rizzato C, Kraft P, Kooperberg C, Petersen GM, Wang Z, Arslan AA, Beane-Freeman L, Bracci PM, Buring J, Canzian F, Duell EJ, Gallinger S, Giles GG, Goodman GE, Goodman PJ, Jacobs EJ, Kamineni A, Klein AP, Kolonel LN, Kulke MH, Li D, Malats N, Olson SH, Risch HA, Sesso HD, Visvanathan K, White E, Zheng W, Abnet CC, Albanes D, Andreotti G, Austin MA, Barfield R, Basso D, Berndt SI, Boutron-Ruault MC, Brotzman M, Büchler MW, Bueno-De-Mesquita HB, Bugert P, Burdette L, Campa D, Caporaso NE, Capurso G, Chung C, Cotterchio M, Costello E, Elena J, Funel N, Gaziano JM, Giese NA, Giovannucci EL, Goggins M, Gorman MJ, Gross M, Haiman CA, Hassan M, Helzlsouer KJ, Henderson BE, Holly EA, Hu N, Hunter DJ, Innocenti F, Jenab M, Kaaks R, Key TJ, Khaw KT, Klein EA, Kogevinas M, Krogh V, Kupcinskas J, Kurtz RC, Lacroix A, Landi MT, Landi S, Le Marchand L, Mambrini A, Mannisto S, Milne RL, Nakamura Y, Oberg AL, Owzar K, Patel AV, Peeters PHM, Peters U, Pezzilli R, Piepoli A, Porta M, Real FX, Riboli E, Rothman N, Scarpa A, Shu XO, Silverman DT, Soucek P, Sund M, Talar-Wojnarowska R, Taylor PR, Theodoropoulos GE, Thornquist M, Tjønneland A, Tobias GS, Trichopoulos D, Vodicka P, Wactawski-Wende J, Wentzensen N, Wu C, Yu H, Yu K, Zeleniuch-Jacquotte A, Hoover R, Hartge P, Fuchs C, Chanock SJ, Stolzenberg-Solomon RS, Amundadottir LT. Genome-wide association study identifies multiple susceptibility loci for pancreatic cancer. Nat Genet. 2014;46:994-1000.

25. Childs EJ, Mocci E, Campa D, Bracci PM, Gallinger S, Goggins M, Li D, Neale RE, Olson SH, Scelo G, Amundadottir LT, Bamlet WR, Bijlsma MF, Blackford A, Borges M, Brennan P, Brenner H, Bueno-De-Mesquita HB, Canzian F, Capurso G, Cavestro GM, Chaffee KG, Chanock SJ, Cleary SP, Cotterchio M, Foretova L, Fuchs C, Funel N, Gazouli M, Hassan M, Herman
JM, Holcatova I, Holly EA, Hoover RN, Hung RJ, Janout V, Key TJ, Kupcinskas J, Kurtz RC, Landi S, Lu L, Malecka-Panas E, Mambrini A, MohelnikovaDuchonova B, Neoptolemos JP, Oberg AL, Orlow I, Pasquali C, Pezzilli R, Rizzato C, Saldia A, Scarpa A, Stolzenberg-Solomon RZ, Strobel O, Tavano F, Vashist YK, Vodicka P, Wolpin BM, Yu H, Petersen GM, Risch HA, Klein AP. Common variation at $2 p 13.3,3 q 29,7 p 13$ and $17 q 25.1$ associated with susceptibility to pancreatic cancer. Nat Genet. 2015;47:911-6.

26. Dimitrakopoulos C, Vrugt B, Flury R, Schraml P, Knippschild U, Wild P, Hoerstrup S, Henne-Bruns D, Wuerl P, Graf R, Breitenstein S, Bond G, Beerenwinkel N, Grochola LF. Identification and validation of a biomarker signature in patients with resectable pancreatic cancer via genome-wide screening for functional genetic variants. JAMA Surg. 2019;154:e190484.

27. Chen Q, Yuan H, Shi G-D, Wu Y, Liu D, Lin Y-T, Chen L, Ge W, Jiang K, Miao Y. Association between NR5A2 and the risk of pancreatic cancer, especially among Caucasians: a meta-analysis of case-control studies. Onco Targets Ther. 2018;11:2709-23.

28. Petersen GM, Amundadottir L, Fuchs CS, Kraft P, Stolzenberg-Solomon RZ, Jacobs KB, Arslan AA, Bueno-de-Mesquita HB, Gallinger S, Gross M, Helzlsouer K, Holly EA, Jacobs EJ, Klein AP, LaCroix A, Li D, Mandelson MT, Olson SH, Risch HA, Zheng W, Albanes D, Bamlet WR, Berg CD, BoutronRuault M-C, Buring JE, Bracci PM, Canzian F, Clipp S, Cotterchio M, de Andrade M, Duell EJ, Gaziano JM, Giovannucci EL, Goggins M, Hallmans G, Hankinson SE, Hassan M, Howard B, Hunter DJ, Hutchinson A, Jenab M, Kaaks R, Kooperberg C, Krogh V, Kurtz RC, Lynch SM, McWilliams RR, Mendelsohn JB, Michaud DS, Parikh H, Patel AV, Peeters PHM, Rajkovic A, Riboli E, Rodriguez L, Seminara D, Shu X-O, Thomas G, Tjønneland A, Tobias GS, Trichopoulos D, Van Den Eeden SK, Virtamo J, Wactawski-Wende J, Wang Z, Wolpin BM, Yu H, Yu K, Zeleniuch-Jacquotte A, Fraumeni JF, Hoover RN, Hartge P, Chanock SJ. A genome-wide association study identifies pancreatic cancer susceptibility loci on chromosomes 13q22.1, 1q32.1 and 5p153.3. Nat Genet. 2010;42:224-8.

29. Li D, Duell EJ, Yu K, Risch HA, Olson SH, Kooperberg C, Wolpin BM, Jiao L, Dong X, Wheeler B, Arslan AA, Bueno-de-Mesquita HB, Fuchs CS, Gallinger S, Gross M, Hartge P, Hoover RN, Holly EA, Jacobs EJ, Klein AP, LaCroix A, Mandelson MT, Petersen G, Zheng W, Agalliu I, Albanes D, Boutron-Ruault M-C, Bracci PM, Buring JE, Canzian F, Chang K, Chanock SJ, Cotterchio M, Gaziano JM, Giovannucci EL, Goggins M, Hallmans G, Hankinson SE, Hoffman Bolton JA, Hunter DJ, Hutchinson A, Jacobs KB, Jenab M, Khaw K-T, Kraft P, Krogh V, Kurtz RC, McWilliams RR, Mendelsohn JB, Patel AV, Rabe KG, Riboli E, Shu X-O, Tjønneland A, Tobias GS, Trichopoulos D, Virtamo J, Visvanathan K, Watters J, Yu H, Zeleniuch-Jacquotte A, Amundadottir L, Stolzenberg-Solomon RZ. Pathway analysis of genome-wide association study data highlights pancreatic development genes as susceptibility factors for pancreatic cancer. Carcinogenesis. 2012;33:1384-90

30. Bergholz J, Xiao Z-X. Role of p63 in development tumorigenesis and cancer progression. Cancer Microenviron. 2012;5:311-22.

31. Rothman N, Garcia-Closas M, Chatterjee N, Malats N, Wu X, Figueroa JD, Real FX, Van Den Berg D, Matullo G, Baris D, Thun M, Kiemeney LA, Vineis P, De Vivo I, Albanes D, Purdue MP, Rafnar T, Hildebrandt MAT, Kiltie AE, Cussenot O, Golka K, Kumar R, Taylor JA, Mayordomo Jl, Jacobs KB, Kogevinas M, Hutchinson A, Wang Z, Fu Y-P, Prokunina-Olsson L, Burdett L, Yeager M, Wheeler W, Tardón A, Serra C, Carrato A, García-Closas R, Lloreta J, Johnson A, Schwenn M, Karagas MR, Schned A, Andriole G, Grubb R, Black A, Jacobs EJ, Diver WR, Gapstur SM, Weinstein SJ, Virtamo J, Cortessis VK, Gago-Dominguez M, Pike MC, Stern MC, Yuan J-M, Hunter DJ, McGrath M, Dinney CP, Czerniak B, Chen M, Yang H, Vermeulen SH, Aben KK, Witjes JA, Makkinje RR, Sulem P, Besenbacher S, Stefansson K, Riboli E, Brennan P, Panico S, Navarro C, Allen NE, Bueno-de-Mesquita HB, Trichopoulos D, Caporaso N, Landi MT, Canzian F, Ljungberg B, Tjonneland A, Clavel-Chapelon F, Bishop DT, Teo MTW, Knowles MA, Guarrera S, Polidoro S, Ricceri F, Sacerdote C, Allione A, Cancel-Tassin G, Selinski S, Hengstler JG, Dietrich H, Fletcher T, Rudnai P, Gurzau E, Koppova K, Bolick SCE, Godfrey A, Xu Z, Sanz-Velez JI, García-Prats MD, Sanchez M, Valdivia G, Porru S, Benhamou S, Hoover RN, Fraumeni JF, Silverman DT, Chanock SJ. A multi-stage genome-wide association study of bladder cancer identifies multiple susceptibility loci. Nat Genet. 2010;42:978-84.

32. Miki D, Kubo M, Takahashi A, Yoon K-A, Kim J, Lee GK, Zo JI, Lee JS, Hosono N, Morizono T, Tsunoda T, Kamatani N, Chayama K, Takahashi T, Inazawa J, Nakamura Y, Daigo Y. Variation in TP63 is associated with lung 
adenocarcinoma susceptibility in Japanese and Korean populations. Nat Genet. 2010;42:893-6.

33. Shiraishi K, Kunitoh H, Daigo Y, Takahashi A, Goto K, Sakamoto H, Ohnami S, Shimada Y, Ashikawa K, Saito A, Watanabe S, Tsuta K, Kamatani N, Yoshida T, Nakamura Y, Yokota J, Kubo M, Kohno T. A genome-wide association study identifies two new susceptibility loci for lung adenocarcinoma in the Japanese population. Nat Genet. 2012;44:900-3.

34. Lan Q, Hsiung CA, Matsuo K, Hong Y-C, Seow A, Wang Z, Hosgood HD, Chen K, Wang J-C, Chatterjee N, Hu W, Wong MP, Zheng W, Caporaso N, Park JY, Chen C-J, Kim YH, Kim YT, Landi MT, Shen H, Lawrence C, Burdett L, Yeager M, Yuenger J, Jacobs KB, Chang I-S, Mitsudomi T, Kim HN, Chang G-C, Bassig BA, Tucker M, Wei F, Yin Z, Wu C, An S-J, Qian B, Lee VHF, Lu D, Liu J, Jeon H-S, Hsiao C-F, Sung JS, Kim JH, Gao Y-T, Tsai Y-H, Jung YJ, Guo H, Hu Z, Hutchinson A, Wang W-C, Klein R, Chung CC, Oh I-J, Chen K-Y, Berndt SI, He X, Wu W, Chang J, Zhang X-C, Huang M-S, Zheng H, Wang J, Zhao X, Li Y, Choi JE, Su W-C, Park KH, Sung SW, Shu X-O, Chen Y-M, Liu L, Kang CH, Hu L, Chen C-H, Pao W, Kim Y-C, Yang T-Y, Xu J, Guan P, Tan W, Su J, Wang C-L, Li H, Sihoe ADL, Zhao Z, Chen Y, Choi YY, Hung J-Y, Kim JS, Yoon H-I, Cai Q, Lin C-C, Park IK, Xu P, Dong J, Kim C, He Q, Perng R-P, Kohno T, Kweon S-S, Chen C-Y, Vermeulen R, Wu J, Lim W-Y, Chen K-C, Chow W-H, Ji B-T, Chan JKC, Chu M, Li Y-J, Yokota J, Li J, Chen H, Xiang Y-B, Yu C-J, Kunitoh H, Wu G, Jin L, Lo Y-L, Shiraishi K, Chen Y-H, Lin H-C, Wu T, Wu Y-L, Yang P-C, Zhou B, Shin M-H, Fraumeni JF, Lin D, Chanock SJ, Rothman N. Genome-wide association analysis identifies new lung cancer susceptibility loci in never-smoking women in Asia. Nat Genet. 2012:44:1330-5.

35. Figueroa JD, Ye Y, Siddiq A, Garcia-Closas M, Chatterjee N, ProkuninaOlsson L, Cortessis VK, Kooperberg C, Cussenot O, Benhamou S, Prescott J, Porru S, Dinney CP, Malats N, Baris D, Purdue M, Jacobs EJ, Albanes D, Wang Z, Deng X, Chung CC, Tang W, Bas Bueno-de-Mesquita H, Trichopoulos D, Ljungberg B, Clavel-Chapelon F, Weiderpass E, Krogh V, Dorronsoro M, Travis R, Tjønneland A, Brenan P, Chang-Claude J, Riboli E, Conti D, Gago-Dominguez M, Stern MC, Pike MC, Van Den Berg D, Yuan J-M, Hohensee C, Rodabough R, Cancel-Tassin G, Roupret M, Comperat E, Chen C, De Vivo I, Giovannucci E, Hunter DJ, Kraft P, Lindstrom S, Carta A, Pavanello S, Arici C, Mastrangelo G, Kamat AM, Lerner SP, Barton Grossman H, Lin J, Gu J, Pu X, Hutchinson A, Burdette L, Wheeler W, Kogevinas M, Tardón A, Serra C, Carrato A, García-Closas R, Lloreta J, Schwenn M, Karagas MR, Johnson A, Schned A, Armenti KR, Hosain GM, Andriole G, Grubb R, Black A, Ryan Diver W, Gapstur SM, Weinstein SJ, Virtamo J, Haiman CA, Landi MT, Caporaso N, Fraumeni JF, Vineis P, Wu X, Silverman DT, Chanock S, Rothman N. Genome-wide association study identifies multiple loci associated with bladder cancer risk. Hum Mol Genet. 2014;23:1387-98.

36. Obazee O, Capurso G, Tavano F, Archibugi L, De Bonis A, Greenhalf W, Key T, Pasquali C, Milanetto AC, Hackert T, Fogar P, Liço V, Dervenis C, Lawlor RT, Landoni L, Gazouli M, Zambon CF, Funel N, Strobel O, Jamroziak K, Cantù C, Małecka-Panas E, Landi S, Neoptolemos JP, Basso D, Talar-Wojnarowska R, Rinzivillo M, Andriulli A, Canzian F, Campa D. Common genetic variants associated with pancreatic adenocarcinoma may also modify risk of pancreatic neuroendocrine neoplasms. Carcinogenesis. 2018;39:360-7.

37. Xu L, Hui L, Wang S, Gong J, Jin Y, Wang Y, Ji Y, Wu X, Han Z, Hu G. Expression profiling suggested a regulatory role of liver-enriched transcription factors in human hepatocellular carcinoma. Cancer Res. 2001;61:3176-81.

38. Baraille F, Ayari S, Carrière V, Osinski C, Garbin K, Blondeau B, Guillemain G, Serradas P, Rousset M, Lacasa M, Cardot P, Ribeiro A. Glucose tolerance is improved in mice invalidated for the nuclear receptor HNF-4Y: a critical role for enteroendocrine cell lineage. Diabetes. 2015;64:2744-56.

39. Klein AP, Lindström S, Mendelsohn JB, Steplowski E, Arslan AA, Buenode-Mesquita HB, Fuchs CS, Gallinger S, Gross M, Helzlsouer K, Holly EA, Jacobs EJ, LaCroix A, Li D, Mandelson MT, Olson SH, Petersen GM, Risch HA, Stolzenberg-Solomon RZ, Zheng W, Amundadottir L, Albanes D, Allen NE, Bamlet WR, Boutron-Ruault M-C, Buring JE, Bracci PM, Canzian F, Clipp S, Cotterchio M, Duell EJ, Elena J, Gaziano JM, Giovannucci EL, Goggins M, Hallmans G, Hassan M, Hutchinson A, Hunter DJ, Kooperberg C, Kurtz RC, Liu S, Overvad K, Palli D, Patel AV, Rabe KG, Shu X-O, Slimani N, Tobias GS, Trichopoulos D, Van Den Eeden SK, Vineis P, Virtamo J, Wactawski-Wende J, Wolpin BM, Yu H, Yu K, Zeleniuch-Jacquotte A, Chanock SJ, Hoover RN, Hartge P, Kraft P. An absolute risk model to identify individuals at elevated risk for pancreatic cancer in the general population. PLOS ONE. 2013:8:e72311.
40. Streicher SA, Klein AP, Olson SH, Amundadottir LT, DeWan AT, Zhao H, Risch HA. Impact of sixteen established pancreatic cancer susceptibility loci in american jews. Cancer Epidemiol Biomarkers Prev. 2017;26:1540-8.

41. Shan Y-S, Chen L-T, Wu J-S, Chang Y-F, Lee C-T, Wu C-H, Chiang N-J, Huang H-E, Yen C-J, Chao Y-J, Tsai H-J, Chen C-Y, Kang J-W, Kuo C-F, Tsai C-R, Weng Y-L, Yang H-C, Liu H-C, Chang JS. Validation of genome-wide association study-identified single nucleotide polymorphisms in a case-control study of pancreatic cancer from Taiwan. J Biomed Sci. 2020;27:69.

42. Willis JA, Olson SH, Orlow I, Mukherjee S, McWilliams RR, Kurtz RC, Klein RJ. A replication study and genome-wide scan of single-nucleotide polymorphisms associated with pancreatic cancer risk and overall survival. Clin Cancer Res. 2012;18:3942-51.

43. Hoskins JW, Ibrahim A, Emmanuel MA, Manmiller SM, Wu Y, O'Neill M, Jia J, Collins I, Zhang M, Thomas JV, Rost LM, Das S, Parikh H, Haake JM, Matters GL, Kurtz RC, Bamlet WR, Klein A, Stolzenberg-Solomon R, Wolpin BM, Yarden R, Wang Z, Smith J, Olson SH, Andresson T, Petersen GM, Amundadottir LT. Functional characterization of a chr13q22.1 pancreatic cancer risk locus reveals long-range interaction and allele-specific effects on DIS3 expression. Hum Mol Genet. 2016;25(21):4726-38.

44. Nakatochi M, Lin Y, Ito H, Hara K, Kinoshita F, Kobayashi Y, Ishii H, Ozaka M, Sasaki T, Sasahira N, Morimoto M, Kobayashi S, Ueno M, Ohkawa S, Egawa N, Kuruma S, Mori M, Nakao H, Wang C, Nishiyama T, Kawaguchi T, Takahashi M, Matsuda F, Kikuchi S, Matsuo K. Prediction model for pancreatic cancer risk in the general Japanese population. PLOS ONE. 2018;13:e0203386.

45. Hublitz P. NIR is a novel INHAT repressor that modulates the transcriptional activity of p53. Genes Dev. 2005;19:2912-24.

46. Wu L, Ma CA, Zhao Y, Jain A. Aurora B interacts with NIR-p53, leading to p53 phosphorylation in its DNA-binding domain and subsequent functional suppression. J Biol Chem. 2011;286:2236-44.

47. Heyne K, Willnecker V, Schneider J, Conrad M, Raulf N, Schule R, Roemer K. NIR, an inhibitor of histone acetyltransferases, regulates transcription factor TAp63 and is controlled by the cell cycle. Nucleic Acids Res. 2010;38:3159-71.

48. Tang J, Hu C, Mei H, Peng L, Li H. CLPTM1L gene rs402710 (C > T) and rs401681 (C > T) polymorphisms associate with decreased cancer risk: a meta-analysis. Oncotarget. 2017:8:102446-57.

49. Yin J, Li Y, Yin M, Sun J, Liu L, Qin Q, Li X, Long L, Nie S, Wei S. TERTCLPTM1L polymorphism rs401681 contributes to cancers risk: evidence from a meta-analysis based on 29 publications. PLoS ONE. 2012;7:e50650

50. Rizzato C, Campa D, Giese N, Werner J, Rachakonda PS, Kumar R, Schanné M, GreenhalfW, Costello E, Khaw K, Key TJ, Siddiq A, Lorenzo-Bermejo J, Burwinkel B, Neoptolemos JP, Büchler MW, Hoheisel JD, Bauer A, Canzian F. Pancreatic cancer susceptibility loci and their role in survival. PLoS ONE. 2011;6:e27921.

51. Wang $X$, Lin X, Na R, Jiang D, Zhang P, Li J, Jin C, Fu D, Xu J. An evaluation study of reported pancreatic adenocarcinoma risk-associated SNPs from genome-wide association studies in Chinese population. Pancreatology. 2017;17:931-5

52. Liu C, Wang Y, Huang H, Wang C, Zhang H, Kong Y, Zhang H. Association, between CLPTM1L-TERT rs401681 polymorphism and pancreatic cancer risk among Chinese Han population. Tumor Biol. 2014;35:5453-7.

53. Yang Y-C, Fu W-P, Zhang J, Zhong L, Cai S-X, Sun C. rs 401681 and rs 402710 confer lung cancer susceptibility by regulating TERT expression instead of CLPTM1L in East Asian populations. Carcinogenesis. 2018;39:1216-21.

54. Yamamoto K, Okamoto A, Isonishi S, Ochiai K, Ohtake Y. A novel gene, CRR9, which was up-regulated in CDDP-resistant ovarian tumor cell line, was associated with apoptosis. Biochem Biophys Res Commun. 2001;280:1148-54.

55. Kim N, Piatyszek M, Prowse K, Harley C, West M, Ho P, Coviello G, Wright W, Weinrich S, Shay J. Specific association of human telomerase activity with immortal cells and cancer. Science (80-). 1994;266:2011-5.

56. Gibbs DC, Orlow I, Kanetsky PA, Luo L, Kricker A, Armstrong BK, AntonCulver H, Gruber SB, Marrett LD, Gallagher RP, Zanetti R, Rosso S, Dwyer T, Sharma A, La Pilla E, From L, Busam KJ, Cust AE, Ollila DW, Begg CB, Berwick $M$, Thomas NE. Inherited genetic variants associated with occurrence of multiple primary melanoma. Cancer Epidemiol Biomarkers Prev. 2015;24:992-7.

57. Yadav D, Lowenfels AB. The epidemiology of pancreatitis and pancreatic cancer. Gastroenterology. 2013;144:1252-61. 
58. Maisonneuve P, Lowenfels AB. Epidemiology of pancreatic cancer: an update. Dig Dis. 2010;28:645-56.

59. Cervantes A, Waymouth EK, Petrov MS. African-Americans and indigenous peoples have increased burden of diseases of the exocrine pancreas: a systematic review and meta-analysis. Dig Dis Sci. 2019;64:249-61.

60. Silverman DT, Hoover RN, Brown LM, Swanson GM, Schiffman M, Greenberg RS, Hayes RB, Lillemoe KD, Schoenberg JB, Schwartz AG, Liff J, Pottern LM, Fraumeni JF. Why do black Americans have a higher risk of pancreatic cancer than white Americans? Epidemiology. 2003;14:45-54

61. Huang BZ, Stram DO, Le Marchand L, Haiman CA, Wilkens LR, Pandol SJ, Zhang Z, Monroe KR, Setiawan VW. Interethnic differences in pancreatic cancer incidence and risk factors: the Multiethnic cohort. Cancer Med. 2019;8:3592-603.

62. Galeotti AA, Gentiluomo M, Rizzato C, Obazee O, Neoptolemos JP, Pasquali C, Nentwich M, Cavestro GM, Pezzilli R, Greenhalf W, Holleczek B, Schroeder C, Schöttker B, Ivanauskas A, Ginocchi L, Key TJ, Hegyi P,
Archibugi L, Darvasi E, Basso D, Sperti C, Bijlsma MF, Palmieri O, Hlavac $\checkmark$, Talar-Wojnarowska R, Mohelnikova-Duchonova B, Hackert T, Vashist Y, Strouhal O, van Laarhoven $H$, Tavano F, Lovecek M, Dervenis C, Izbéki F, Padoan A, Małecka-Panas E, Maiello E, Vanella G, Capurso G, Izbicki JR, Theodoropoulos GE, Jamroziak K, Katzke V, Kaaks R, Mambrini A, Papanikolaou IS, Szmola R, Szentesi A, Kupcinskas J, Bursi S, Costello E, Boggi U, Milanetto AC, Landi S, Gazouli M, Vodickova L, Soucek P, Gioffreda D, Gemignani F, Brenner H, Strobel O, Büchler M, Vodicka P, Paiella S, Canzian F, Campa D. Polygenic and multifactorial scores for pancreatic ductal adenocarcinoma risk prediction. J Med Genet. 2020. https://doi.org/10. 1136/jmedgenet-2020-10696.

\section{Publisher's Note}

Springer Nature remains neutral with regard to jurisdictional claims in published maps and institutional affiliations.
Ready to submit your research? Choose BMC and benefit from:

- fast, convenient online submission

- thorough peer review by experienced researchers in your field

- rapid publication on acceptance

- support for research data, including large and complex data types

- gold Open Access which fosters wider collaboration and increased citations

- maximum visibility for your research: over $100 \mathrm{M}$ website views per year

At BMC, research is always in progress.

Learn more biomedcentral.com/submissions 